\title{
Chapter 1 \\ Roma Westward Migration in Europe: Rethinking Political, Social, and Methodological Challenges
}

\author{
Stefano Piemontese and Tina Magazzini
}

The idea for this book stemmed from two symposia that brought together scholars from a range of different countries and disciplines to reflect upon the political and legal context of the mobility of Romani citizens in Europe. Our interest in this topic started with the adoption of a EU Framework for National Roma Integration Strategies in 2011, when Member States were requested to develop integration strategies that were explicitly yet not exclusively targeted at their Roma populations (European Commission 2011). Even though this policy scheme represented an effort to overcome the inadequacies of the anti-discrimination directives ${ }^{1}$ to address the social and institutional discrimination suffered by Roma people in Europe, tangible results of such measures have so far been lacking. The symposia, titled "Roma Westward Migration in Europe: Rethinking Political, Social, and Methodological Challenges", ${ }^{2}$ addressed the emergence of Roma-specific policies alongside an increasing concern about migration and diversity management. The drive to bring

\footnotetext{
${ }^{1}$ These are the Council Directive 2000/43/EC of 29 June 2000, implementing the principle of equal treatment between persons irrespective of racial or ethnic origin, and the Council Directive 2000/78/EC of 27 November 2000, establishing a general framework for equal treatment in employment and occupation.

${ }^{2}$ Under this title, two symposia were organized during the VIII Congreso sobre Migraciones Internacionales (Granada, September 16-18, 2015). The first panel aimed at promoting a reflection and debate around the political and the legal context of "Roma migration" within the EU. The second panel aimed at addressing the research gap on the same phenomenon from a more anthropological perspective, and especially through the theories of migration. Both symposia were co-organized with Dr. Giuseppe Beluschi Fabeni and Dr. Elisabeth Gómez Oehler and have been supported by the Marie Skłodowska-Curie INTEGRIM Initial Training Network and the FP7 MigRom Project.
}

S. Piemontese ( $\square)$

EMIGRA Research Group on Education, Migration and Childhood, Department of Social and Cultural Anthropology, Autonomous University of Barcelona, Bellaterra, Barcelona, Spain e-mail: piemontese.stefano@gmail.com

T. Magazzini

Robert Schuman Centre for Advanced Studies, European University Institute, Florence, Italy e-mail: tina.magazzini@eui.eu

T. Magazzini, S. Piemontese (eds.), Constructing Roma Migrants,

IMISCOE Research Series, https://doi.org/10.1007/978-3-030-11373-5_1 
together different disciplinary and methodological approaches to "Roma migration"3 in Europe, and to explore how such phenomenon has been narrated, policed, politicized or ignored was - and is - rooted in four main considerations. Firstly, we are convinced that putting the focus squarely on the so-called "Roma westward migration" and problematizing the assumptions that underpin such a label contributes to uncover the structural inconsistencies of the European "Roma integration" framework and to question its overall political approach. Secondly, the intersections and overlaps between the categories of "Roma" and of "migrants" show how the classifications of deservingness and of access to welfare resources have shifted in recent years, making explicit the under-studied link between inclusive and securitarian policies. Thirdly, we believe that "Roma migration" provides a unique testing ground to understand how those portrayed as "the others" in contemporary Europe cope and develop counter-strategies in a system in which their options are limited. Fourthly and finally, we strongly support ethnographic accounts as a useful means to evaluate public policies at the local level, as they offer rich data that cannot be captured by national statistics or by surveys alone.

\subsection{Problematizing the Assumptions}

Regarding the need to problematize "Roma migration", this is a desideratum which has in recent years been shared by many Romani scholars and social scientists interested in equality policies in order to overcome the dangers of a narrow and selfserving knowledge-production (Baar and Ivasiuc 2019; Law and Kovats 2018; Matras and Leggio 2018; Surdu 2016; Y1ld1z and Genova 2017). Within this strand of research, this book emerges from the awareness that a variety of understandings and definitions exist about "who the Roma are", and that this diversity triggers very heterogeneous political approaches and actions. The scope and limits of a EU common framework aimed at promoting "Roma integration" are largely conditioned by the divides between Western and Eastern European countries, between colour-blind and identity-policy traditions, between the understanding of "Roma" as a domestic or European issue. The question of migration becomes therefore ever more salient.

A departing consideration of the reflections that can be found in this volume is that the international mobility of the Roma has strongly contributed to the Europeanization of the "Roma issue" (van Baar 2015, 2017b; Vermeersch 2012). It was largely the political response of local and national governments to the arrival of foreign (albeit EU citizens) Roma in their territories that convinced EU institutions

\footnotetext{
${ }^{3}$ While the term "Roma migration" can be found at times in brackets and at times not throughout the volume, it should always be understood as a political category, which emerged in the interplay between media narratives, institutional categories and integration policies. This understanding does not negate the existence of the Roma minority nor of the fact that a number of Roma have migrated in the past and continue to do so. It does however challenge the idea that all Roma migrants share common characteristics and that "Roma migration" is a phenomenon that is somehow organized, cohesive or coordinated amongst different groups and countries.
} 
to adopt a common strategy for "Roma integration". However, the formal recognition of "Roma people" as a transnational minority, as well the adoption of "Roma ethnicity" as an organizing principle for the redistributive policies pursued by the European Union, raises some conceptual questions related to the incorporation of ethno-specific policies in colour-blind policy settings. In translating the EU framework into national strategies, Roma transnational mobility reawakens and shifts the policy and philosophical debates on the dialectic relation between socio-economic redistribution and identity recognition from a multi-national to a local context. Furthermore, the coexistence of both "national" and "immigrant" Roma on a same territory, as well as under the same policy framework, is challenging the making of a pan-European Roma identity, with potential repercussions that stereotyped and racialised perceptions of the former may have on the development of policies for the latter, and vice versa. These incoherencies emerge strongly with regard to the crafting of public policy practices developed at a local level, as well as in terms of legal framework. Roma migration emphasizes the existent gap between the rigid understanding of ethnicity embedded in the policies for Roma on the one hand, the wide heterogeneity of national approaches towards "Roma diversity" (from national majorities) on the other hand, and Roma inner diversity itself.

Migration from Central and Eastern Europe triggered policies towards Roma at the EU level and raised the issue to the international agenda more than any poverty level or discrimination that the Roma might suffer could have done. In spite of that, as Iulius Rostas put it, "That's the irony of it. Roma were put on the agenda because of migration, but migration isn't dealt with in the strategy" (in Ryder et al. 2015: 176). Indeed, the EU framework for National Roma Integration Strategies does not make any distinction between national and non-national Roma minorities, leaving Member States free to define the target population of their Roma-targeted programs according to their domestic priorities and political concerns. In practice, while the "Europeanization of Roma representation" (van Baar 2017a) provided a solid discursive rationale for the development of an EU "Roma integration" strategy, it also required to categorize a wide range of very heterogeneous groups within the single administrative category of "the Roma".

The progressive incorporation (or lack of incorporation) of Roma migrants in the Roma-targeted policies of European countries who host both national and nonnational Roma groups is influenced by various financial, ideological and political elements, as the chapters of this book show. The increasingly accepted categorization of "the Roma" as a transnational population fostered the "trickle down" adoption of the EU official discourse on Roma people. This is a narrative that sees them as both victims of racism, discrimination and social exclusion and as a "true European minority" (Council of Europe 1993) - Europe's largest (European Commission 2012a: 2). However, the distribution of EU funding for "Roma inclusion" coupled with the need to give a policy response to the freedom of movement of impoverished Romanian and Bulgarian Roma citizens, resulted in a puzzle of measures of both inclusion and securitization of the "new" Roma. 


\subsection{The Securitarian Shift of "Roma Integration" Initiatives}

Alongside the development of policies for "Roma integration" we also witnessed a proliferation of restrictive policies implicitly addressed at this population, mainly in the form of administrative regulations. Since 2014, after 7 years of labour rights' restrictions for EU citizens from Romania and Bulgaria, ${ }^{4}$ several countries started applying ever more restrictive legal frameworks to the freedom of movement of EU workers, limiting their access to basic public services. Meanwhile, the mechanisms of identification that are inherent to the targeting procedures of "Roma integration" policies have either tended to exclude "Roma migrants" from the opportunity to benefit from integration programs, or pushed local administrations to establish a strict criteria to access institutionally-defined paths of "social inclusion". As a result, the interventions aimed at impoverished Roma from other EU countries have mostly involved forced evictions, voluntary return programs, and begging bans: "exclusive but not explicit" initiatives that both mirror and subvert the targetedapproach advocated by the European institutions (Magazzini and Piemontese 2016). All of this takes place in a context which has seen an escalation of public and political discourses that openly reject "Roma migration", encourage expressions of Antiziganism, and is accompanied by culturalist interpretations of residential mobility, housing conditions and economic strategies that spill over into policies.

The chapters included in this collection show that EU citizens of Roma ethnicity end up being recognized as beneficiaries of specific actions - of both inclusion and securitization - only when their presence is perceived as a threat to public order. But the securitarian facet of the "Roma integration" programs is neither accidental nor surprising: it rather represents the inevitable consequence of the original yet untold concerns towards the control of "Roma migration" which informed the design of the "Roma integration" policies in the first place, and which keeps shaping a wide range of policy measures addressed to Roma. Against this backdrop, we interpret the development of a legal framework for "Roma integration" as a policy device that has allowed local government to legitimize pre-existent administrative practices of deservingness and to create additional criteria of accession to social rights for ethnically-defined groups of people. The current framework has often been used to distinguish between "deserving" and "undeserving" Roma, much in the same way in which States attempt to create a demarcation between "real" and "bogus" asylum seekers, in short between those who are granted the right to be included and those who are not.

\footnotetext{
${ }^{4}$ According to the "Treaty concerning the accession of the Republic of Bulgaria and Romania to the European Union" (Treaty of Accession 2005), old member states have the right to impose a transitional period of 2 years on labour rights of the new member's citizens, extendable for additional 3 years, and of 2 more years in case of serious proof that labour from new member states would be disruptive to the market. Many old member states (France, Germany, Spain, Austria, Belgium, Netherlands, Luxembourg, United Kingdom) made use of all the extensions possible to delay allowing working permits to Romanian and/or to Romanian nationals. Since Romania and Bulgaria joined the European Union in 2007, such transitional period ended in 2014.
} 
Building on the contradictions triggered by the encounter between benevolent policies for "Roma integration" and the politics of "Roma securitization", this book aims to untangle the ethno-political construction of "Roma migrants". While we lay no claim on defining who "Roma migrants" are, the administrative category is produced by specific narratives mobilised at a European level and by policies implemented in local contexts. The interplay between these two dimensions is of considerable importance. On the one hand, the "Roma issue" became of policy and scholarly relevance greatly through the EU impulse, which has in turn shaped national and local discourses and practices. On the other hand, the local governance of the "Roma issue", with its bordering policies around access to services, reveals much of how such policies work in practice (van Baar 2017a; Vrăbiescu and Kalir 2017). As the chapter of Vera Messing will argue, key issues and terms dealt with in this volume, such as "Roma" and "migrant" are not objective or unproblematic: every minority group is at least to some extent a social construct and the process of categorizing who is an immigrant, who is a Roma and who requires integration is an important aspect of how identities are created. Thus, the red line that connects the single contributions of this volume - both to each other and to the different levels of analysis - is the construction of the "Roma migrant" as something that is produced and maintained by public discourse, and whose imaginary informs, at the same time, both the design and the implementation of local policies towards people who are identified as such.

\subsection{Coping Strategies and Counter-Narratives}

If the mainstream European narrative of who these "Roma migrants" are is one that has been characterized mainly by a welfarist and emergency-driven approach, such an approach is not the only account available. Alternative counter-narratives exist which are made up of individual perspectives, experiences, and interpretations, and these are the stories that this book provides a space for.

With the emergence of the "Roma issue" as a politically constructed problem in Europe, the concerns of the European Member States and of their institutions regarding the phenomenon of "Roma migration" have become a testing ground for how we conceive and negotiate "the other", both nationally and internationally. It is our opinion that research on the management of the so-called "Roma issue" has much to contribute to the understanding of the discourses, procedures and potential solutions that have to do with the so-called "refugee crisis". 5 Similarly, research on low-income immigrant Roma and their relations with local public policies, can shed light on broader neoliberal welfare/workfare policies in times of (financial and democratic) predicament.

In this respect, the developmentalist approach of the Roma Framework, with its sectorial compartmentalization in education, housing, employment and healthcare,

${ }^{5}$ For a problematisation of the term "refugee crisis" and "migration crisis" see Cantat (2015a, b). 
raises important interrogations about the portraying and targeting of Roma people as "victims of racism, discrimination and social exclusion" (Fundamental Rights Agency and UNDP 2012: 3). This approach contributes, at least to some extent, to corroborate the idea that Roma identity and social exclusion are two overlapping categories. One might also suggest that the Roma Framework opted for a welfarist narrative rather than an identity or anti-discrimination one in order not to interfere with a very heterogeneous range of national approaches towards the management of ethno-cultural diversity in Europe. Still, the adoption of "Roma ethnicity" as an organizing principle for the redistributive policies pursued by the European Union leaves us with a fundamental problem: ethno-specific programs are difficult to implement in colour-blind political settings. How do those who find themselves caught in such definitions and policies react to them, use them, reject them or hide from them?

Moving from these considerations, this volume aims at offering an alternative perspective on the normative claims about Roma minorities as belonging within a "deficit" or "marginalised" paradigm (either in cultural or socio-economic terms), which effectively constructs them as a policy problem, rather than the regimes of inequality upon which our societies are built, and of which Roma individuals are part and parcel of. As Salman Rushdie wrote on race relations in the United Kingdom and on the so-called "problem" of the integration of minoritized groups:

\footnotetext{
You talk about the Race Problem, the Immigration Problem, all sorts of problems. If you are liberal, you say that black people have problems. If you aren't, you say that they are the problem. But the members of the new colony have only one real problem, and that problem is white people... Racism, of course, is not our problem. It's yours. We simply suffer the consequences of your problem. (Rushdie 1982)
}

While there are important differences between (and within) Roma minorities in contemporary Europe and black people in the United Kingdom of the 1980s, the issue of narrating the problem as one of the majorities, rather than of the minorities, remains painstakingly relevant. In keeping with this approach that sees as a pressing necessity the investigation of what "European identity" is understood to be, and how categories of exclusion from such "Europeaness" are constructed (Y1ldiz and Genova 2017), the present volume does not claim to advance any novel finding about the nature, character or identity of Roma minorities or of migrants. Rather, we aim at exposing some of the dynamics through which categories of inclusion and exclusion are created are maintained, thus contributing to rethinking European societies and identities through an exploration of "our problem", racism. In this respect, we feel that it is only fair to acknowledge that none of the authors of this volume are Roma, and while we welcome feedback, input, criticism and help in solving this problem from Roma scholars interested in these issues, we can only recognize that academia is by no means immune from structural discrimination. In practical terms, while we received a considerable number of what we considered to be valuable contributions in response to our call for papers for the symposia "Roma Westward Migration in Europe: Rethinking Political, Social, and Methodological Challenges", none of them came from Roma scholars. This may well be blamed on our incapacity to reach out to those Roma authors whose work we look up to and engage with; on 
the economic and time constraints imposed by academic conferences; or on both. Be it as it may, this book hopes to be part of a conversation that does not appropriate or overlook the work being carried out from critical perspectives by Roma scholars on similar issues (Bogdan et al. 2018: 5).

Rather, we present a cross-disciplinary and wide-ranging collection of policy analysis and case studies, including practical experiences of social intervention, in the hope to render more mainstream the usage of ethnographic accounts as a tool for policy understanding and evaluation.

\subsection{The Contribution of an Ethnographic Approach to "Roma Migration"}

As above-mentioned, one core driver of this book is that ethnographic studies, which are generally not associated with policy evaluation, can offer an insight into the effects of the European legal and political framework on the life of "Roma migrants" in western European countries. Over the past decades, the integration of minorities and of migrants in Europe has become a highly topical and politicized issue, often framed as a social problem. This has fuelled a rich academic production on ethnicity, cultural rights and migration, but such studies tend to remain compartmentalized according to academic fields, groups and territories analysed. Also, as a result, the two fields of diversity management and migration have so far generally been studied in isolation from each other (de Jong 2016). This volume's aim is to contribute to bridge the existing gap between these two fields, to move beyond methodological nationalism focusing more on the local dimension, and to offer concrete examples of local governance associated to "Roma migration".

In short, moving from the intellectual need to put some order into the wide heterogeneity of approaches towards "Roma diversity", we intend to integrate legal, political and sociological perspectives with critical ethnographic accounts. This choice is rooted in our understanding of social anthropology as a valuable tool for assessing the implementation of public policies. The ten Common Basic Principles on Roma Inclusion (a guidelines toolkit developed by European Commission for both policy makers and practitioners' in charge of programmes and projects for Roma) stress the importance of policy evaluation to make the Roma initiatives "appropriate to the situation on the ground" (European Commission 2012b). Yet, the strategic approaches that end up being adopted often are inherently skewed towards universalistic tools, such as "best practices", which need to be evaluated carefully as their replicability rests on local contexts which vary significantly. Conversely, ethnographic accounts bring human behaviour back into the picture, and connect political and academic debates back to the reality experienced by their subjects of intervention or research. In a broader sense, the proposed book represents an attempt to assess, both conceptually and empirically, the implementation of the 2011 EU framework for "Roma integration". Until now, country-specific evaluations have been realized by civil-society organizations. This book is meant to be an 
assessment, from an academic standpoint, of the over 7 years of the common framework for "Roma integration".

Finally, the book endeavours to establish a link between the micro, meso, and macro-level of inquiry. "Roma migration" has been a key issue in contemporary European cohesion policies for over a decade, but its multifaceted and complex dynamics have seldom been considered in connection with each other. This, in our opinion, has prevented a comprehensive theoretical and empirical understanding of current trends for local level action in the challenging processes of Roma migration management in Europe. This book's perspective is that there is a need to transcend the current conception of the local level as an insular space suited to micro-level studies of multicultural experience in favour of an understanding of local governance as a nodal point in multi-level and transnational exchanges. The key objective of the volume is therefore to analyse the dissonances, overlaps and synergies that characterize the design and implementation of policies for "Roma" in Europe: EU institutions, local and national administrations, third sector organizations, and the agency of both Roma and non Roma populations themselves. To this end, the structure of the book is organized in a general-to-particular way.

\subsection{Book Structure}

The results of our call for considering different disciplines and experiences in Roma integration processes are presented in the proposed volume in the following, tripartite structure.

A first part (Chaps. 2, 3, 4, and 5) analyses the different "frames" - methodological, legal, policy, and media - that exist among expert knowledge on "Roma migration". The book opens with Vera Messing, who gives a critical overview of the conceptual and methodological aspects of researching "Roma migration". In doing so, she raises the issue of research ethics and of the responsibility of researchers during the processes of knowledge production about migration of Roma citizens. Although research in Romani studies have long been in the constructivist paradigm, "Roma migration" risks spurring new tendencies of essentialisation of the Roma, and this contribution aims at warning against such a risk. The second chapter by Nuno Ferreira questions the legal adequacy of EU actions with regards to Roma minorities. His contribution aims to explore how the EU legal framework has developed in relation to "Roma issues" beyond free movement and forced expulsions. In doing so, this contribution goes beyond the usual disjointed analysis of discrete policy aspects and puts forward a comprehensive and critical analysis of the key Roma-related EU initiatives and norms. Building on the analysis of a broad range of legal instruments, policy papers and case law, the author questions the social integration approach and advocates for a more holistic approach. Moving from a legal to a policy-centred analysis of EU initiatives, Tina Magazzini, Enrica Chiozza and Monica Rossi reflect on the shortcomings of the emergency management of the "Roma issue" from a policy implementation perspective, tracing the soft policy 
actions that led to a framework for the National Roma Integration Strategies (NRIS). They find that the efforts of implementing the NRIS and of investing integration funds at the local level encounter significant obstacles in the lack of administrative capacity, political will, and practical challenges to identify the needs and match them to sustainable solutions. Their chapter describes how EU initiatives work in this field, focusing on the need to involve the local level through the concrete case of the ROMACT programme. In Chap. 5, which analyses how the UK media portrayed Roma migrants in the build-up to the British EU referendum, Viktor Leggio shows how the mobilisation of images about Roma migrants to the UK contributed to reshaping the debate around the impact of migration on the welfare system. By combining textual analysis of national media reports, parliamentary debates and national law with observations at the local level, the author highlights how the narrative shifted from the need to reform the benefit system, to the need to reduce migrants' access to the system. The analysis covers the period between the enlargement of the EU to Romania and Bulgaria (January 2007) to Cameron's announcement of his agenda for the negotiations with the EU (November 2014).

Building upon these broad frameworks, the remaining contributions are largely based on ethnographic case-studies and are divided into two sections.

The second part of the book (Chaps. 6, 7, 8, and 9) focuses mainly on the links between integration and securitization policies that are targeted at "Roma migrants". This section opens with the chapter by Marianna Manca and Cecilia Vergnano who enquire into how a local inclusion project (La Città Possibile) that was aimed at ensuring the right to housing to the dwellers of a "Roma camp" in Turin, Italy, has contributed to create new boundaries between deserving and undeserving "Roma migrants". The chapter also highlights the limits of the selective, ethnically-targeted housing policies, and reports the conflicts that such policies produce in a context where the "housing crisis" is increasingly affecting wider cohorts of the population. Ioana Vrabiescu, in the following chapter, provides a critical account of the politics of repatriation presented as politics of benevolence in Spain. Taking the city of Madrid as a case study, this chapter documents and analyses temporary devices of governance that both limit and force the mobility of Romani families from Romania. Implemented by local authorities through specific policies, temporary devices of governance deliver an enforced pressure on Romani migrants who are seen as prospective "failed" subjects of integration and potential returnees. Chapter 8, by Eberhard Raithelhuber, investigates the socio-material production and regulation of the ethno-political figure of the "Roma beggar" through the prism of a regime-of(im)mobility approach. Based on an ethnographic study, core aspects of this regime for "Roma beggars" are analysed on a micro-scale: criminalizing transport, invisibilising borders, educating beggars, victimization, stillness and deportability. His chapter investigates the everyday social and physical infrastructures and logistics for (im)mobility, imaginaries of (im)mobility and discursive technologies. The key insight is that the "stilled, able beggar" is the only legitimate form of begging in the light of a community of good and able citizens: as this figure is practically unrealizable and deceptive, it flips into the "Roma beggar". In Chap. 9, Joanna Kostka examines the discourse on "Roma exclusion" in the context of European migration 
policy, presenting key findings from the case study of Romanian Roma migrants in the city of Wroclaw in Poland. Building on equality scholarship, this chapter argues that portrayal of Roma as "welfare migrants" who move across Europe exploiting the generosity of welfare states, legitimizes hostile public interventions that negate official commitments to the Free Movement principle.

The third part (Chaps. 10,11, 12, and 13), while it has much in common with the second group of chapters in terms of methodology and tools employed, shifts the attention from the policies targeted at "Roma migrants" to the coping strategies and the counter-narratives of those who find themselves treated as "objects" of these initiatives. Picking up from the British narratives on Roma migrants described in Chap. 5, Veronika Nagy reflects on the role of UK welfare surveillance and on the outsourced social services that deal with Central European Roma. The long-standing prejudiced perception of Roma as profiteers unwilling to integrate became the basis for concerns about a "threatening flood" of Roma westward. As a result, control strategies allegedly aimed to ensure security, have legitimated excessive policing and surveillance of migrants. The "mechanisms" applied for sorting and excluding unwanted Roma communities gradually replaced migration policies as a new process of selection regarding undesired European migrants from A8 countries. This chapter provides an empirical analysis of the effects of these sorting measures and on how the targeted groups either comply or circumnavigate these regulations in London. In Chap. 11, Jovana Kzenevic investigates the ways in which Roma from Serbia who sought and have been denied asylum protection in Germany, exert their agency as social actors and, challenging structural constraints, contest the tendency to "victimize" Roma populations. The seeking of asylum by the Roma from Serbia, as one of the main patterns of their migration, has come to the centre of the debate about the rights of obtaining asylum within the existing EU asylum policies, while enforcing the discourse of "false asylum seekers" and "welfare migrants". By revealing the complex reality within which Roma from Serbia choose to migrate in the form of asylum seekers, the study challenges the discourse of "false asylum seekers" and overcomes the simplification caused by this labelling. In Chap. 12, Camilla Ida Ravnbøl looks at the economic coping strategies developed by Roma from Romania in the marginal economy of homelessness in Copenhagen, as surviving mechanisms to deal with existing bureaucratic constraints. The chapter proposes the concept of "patchwork economy" to frame the micro economic strategies that the badocari ("bottle people") engage in. Besides illustrating how debt constitutes the background quilt against which the patchwork economy is continuously reconfigured, the chapter presents analytical insight into the interconnectedness between the micro economy of the Roma household and the broader social and political context of Romania. Finally, in the last chapter, Julija Sardelić traces life histories of Slovenian citizens who identify as Roma and have been mobile between Slovenia and Austria because of employment opportunities. The general aim of her chapter is not to point out a pattern that could be labelled as either Romani migration or mobility, but rather to show that there are alternative narratives to what is usually seen as "Romani migration" in Europe. The chapter seeks to point to differing mobility 
practices by Roma in the EU, which are usually not discussed in public debates and are not connected to "Romani migration".

\subsection{Conclusion}

This book is based on the assumption that the policy and philosophical debates on the international mobility of Roma people should be approached from a multi-scalar perspective. Since the 1980s, geographers have used "scale", "rescaling" and "multiscalarity" as analytical categories, meaning that "localities are places constituted within multiple intersecting trajectories of power" (Çağlar and Glick-Schiller 2015). This also means that "the geographical scale at which political power and authority is located does not constitute a natural order, but rather is constructed and subject to change" (Leitner in Sheppard and McMaster 2008). Building on this tradition, this volume aims at exploring how the processes of mutual constitution of the local, regional, national and global have constructed "Roma migrants".

In doing this, we believe that there is a strong need to overcome the "ethnic frame of reference" which, more or less consciously, characterizes much of the research on integration and migration policies whenever it comes to both Roma people and to migrant individuals (Tremlett 2009, 2014). In our opinion, a targeted approach in research - if it is constantly and solely associated to social marginalization - runs the risk of contributing to problematize an ethnic group which is already under the spotlight, while at the same time normalizing the adoption of categories of ethnic classification to describe social phenomena that are better explained in the broader framework of the management of socio-economic diversity in the era of neoliberalism. Against this background, the question is not only how much of the imaginary about the "Roma migrant" is reproduced by European discourse and local practices, but also how much of this representation is reproduced in our research. Both this volume and the event that inspired it obliged us to face important ethical questions concerning our positioning as researchers regarding the so-called "Roma issue".

Neither the conference panels nor this book were intended to be about Roma themselves, but rather about the policies that concern them. We wanted a collection of contributions that showed how policies for "Roma inclusion" work in practice, and how they intersect and overlap with policies aimed at migrants, but we ended up collecting contributions mainly on policies of securitization and control of impoverished Roma from other Member States. Are we contributing to reproduce the imagery of the "Roma migrant" that we had set out to help deconstruct? Or do the individual and collective stories told in this volume reveal that policies tend to address Roma migrants specifically only when they are perceived as a menace?

As several chapters show, looking at the relation between European policies and the subjective experience of those people who could potentially benefit or who suffer from them, represents in all respects a way to research non-Roma alongside Roma. However, in the words of Vera Messing (in this volume) it is exactly the vagueness of "Roma migration" that makes this phenomenon "suitable to be used as 
a symbol to call forth society's deep, historic fears of the Other rooted in racialized prejudice". Then, before being a symbol, we must consider that Roma are first of all the target of specific discourses, actions and policies. Such narratives and policies hold the potential to either reduce or to reinforce existing inequalities, and in observing their dynamics and effects we hope to contribute to the former. One could indeed argue that, if the impact of the "targeted" policies leaves much to be desired, perhaps we should do away with them altogether, and focus instead on the universalistic welfare programs that have the advantage of applying indistinctly to all citizens who meet the minimum requirement of residence. As some of the chapters in this volume will show, this is however a bitter-sweet hope.

Nowadays, at a time in which the current model of European integration is questioned by newly born populisms charged with an old rhetoric on state-sovereignty, it is essential to move a constructive critique to those European policies that hold the potential to both promote social justice and shed light on the existing contradictions between the national and local levels.

\section{Bibliography}

Bogdan, M., Dunajeva, J., Junghaus, T., Kocze, A., Rostas, I., Rovid, M., \& Lezi, A. (Eds.). (2018). Critical Romani studies (Vol. 1). Budapest: Central European University Press.

Çağlar, A., \& Glick-Schiller, N. (2015). A multiscalar perspective on cities and migration. A comment on the symposium. Sociologica, 2/2015. Il Mulino, Bologna.

Cantat, C. (2015a). Rethinking mobilities: Solidarity and migrant struggles beyond narratives of crisis. Intersections. East European Journal of Society and Politics, 2(4), 11-32.

Cantat, C. (2015b, December 18). Migration struggles and the crisis of the European project. Budapest: FocaalBlog. Retrieved from www.focaalblog.com/2015/12/18/ celine-cantat-migration-struggles-and-the-crisis-of-the-european-project

Corriere della Città. (2017, September 30). L'associazione dei Rom denuncia Roma Capitale per truffa: "spariti" $i$ soldi dei fondi europei. Roma. Retrieved from http://www.ilcorrieredellacitta.com/news/nazione-rom-denuncia-roma-capitale-ad-anac-truffa.html

Council of Europe. (1993). Gypsies in Europe (Recommendation 1203, Parliamentary Assembly, 1993) (Vol. Parliament).

Crapanzano, V. (1980). Tuhami, portrait of a Moroccan. Chicago: Chicago University Press.

de Jong, S. (2016). Converging logics? Managing migration and managing diversity. Journal of Ethnic and Migration Studies, 42(3), 341-358.

de Laat, J. (2010). World Bank -Europe and Central Asia: Economic costs of Roma exclusion economic cost of Roma exclusion calculating economic costs of Roma exclusion. The World Bank.

European Commission. (2008a). COM(2008) 418 final. A renewed commitment to social Europe: Reinforcing the Open Method of Coordination for Social Protection and Social Inclusion. Brussels.

European Commission. (2008b). Commission Staff Working Document accompanying the COM(2008) final 420 "Non-discrimination and equal opportunities: A renewed commitment. European Commission communication.

European Commission. (2010). Communication from the Commission to the Council, the European Parliament, the European Economic and Social Committee and the Committee of 
Regions. The social and economic integration of the Roma in Europe. Retrieved from http:// eur-lex.europa.eu/legal-content/en/ALL/?uri=CELEX:52010DC0133

European Commission. (2011). Communication from the Commission to the European Parliament, the Council, the European Economic and Social Committee of Regions. An EU Framework for National Roma Integration Strategies up to 2020. Retrieved from http://eur-lex.europa.eu/ legal-content/en/ALL/?uri=CELEX:52011DC0173

European Commission. (2012a). Communication from the Commission to the European Parliament, the Council, the European Economic and Social Committee of the Regions. National Roma Integration Strategies: A first step in the implementation of the EU Framework. Retrieved from http://eur-lex.europa.eu/legal-content/en/ALL/?uri=CELEX:52012DC0226

European Commission. (2012b). Vademecum. The 10 common basic principles on Roma inclusion. For diversity against discrimination. An initiative of the European Commission. Brussels: EC [Commission of The European Communities].

European Roma Rights Centre. (2004). Stigmata: Segregated schooling of Roma in Central and Eastern Europe. Budapest: ERRC.

European Union Agency for Fundamental Rights. (2011). EU-MIDIS technical report. Methodology, sampling and fieldwork.

European Union Agency for Fundamental Rights. (2016). Second European Union minorities and discrimination survey Roma - Selected findings.

Fundamental Rights Agency. (2009). The situation of Roma EU citizens moving to and settling in other EU Member States.

Fundamental Rights Agency, \& UNPD. (2012). In Fundamental Rights Agency (Ed.), The situation of Roma in 11 EU Member States. Survey results at a glance. Luxembourg: Office of the European Union.

HuffPost. (2017, July 23). Roma paga il "mental coach" per convincere $i$ rom a lavorare. Roma. Retrieved from http://www.huffingtonpost.it/2017/07/23/ roma-paga-il-mental-coach-per-convincere-i-rom-a-lavorare_a_23043738/

Kovats, M. (2001). Problems of intellectual and policial accountability in respect of emerging European Roma policy. Journal on Ethnopolitics and Minority Issues in Europe, 2(1), 1. Retrieved from http://www.ecmi.de/fileadmin/downloads/publications/JEMIE/2001/Focus112001KovatsComment.pdf

Law, I., \& Kovats, M. (2018). Rethinking Roma. Identities, politicisation and new agendas. London: Palgrave Macmillan.

Magazzini, T., \& Piemontese, S. (2016). Roma migration in the EU: The case of Spain between "new" and "old" minorities. Migration Letters, 13(2), 228-241.

Matras, Y., \& Leggio, D. V. (Eds.). (2018). Open borders, unlocked cultures. Romanian Roma migrants in Western Europe. London: Routledge.

Open Society Foundations. (2010). No data - No progress. Country findings.

Ovalle, O. M., \& Mirga, A. (2014). The myth of the Spanish model of Roma inclusion. Retrieved from https://www.opensocietyfoundations.org/voices/myth-spanish-model-roma-inclusion

Rushdie, S. (1982). The New Empire within Britain. Retrieved from https://public.wsu. edu/ hegglund/courses/389/rushdie_new_empire.htm

Ryder, A., Kocze, A., Rostas, I., Dunajeva, J.-E., Bogda, M., Taba, M., Junghaus, T. (2015). Nothing about us without us? Roma participation in policy making and knowledge production. Rights Journal of the European Roma Rights Centre (Vol. 2). Budapest.

Sheppard, E., \& McMaster, R. B. (2008). Scale and geographic inquiry: Nature, society, and method. New York: Wiley.

Sigona, N., \& Treheran, N. (Eds.). (2009). Romani politics in contemporary Europe: Poverty, ethnic mobilisation and the new liberal order. Basingstoke: Palgarve Macmillan.

Stone, D. (2001). Getting research into policy? Third Annual Global Development Network Conference on "Blending Local and Global Knowledge", Rio de Janeiro (Vol. 10). 
Surdu, M. (2016). Those who count. Expert practices of Roma classification. Budapest: Central European University Press.

The World Bank. (2012). Reducing vulnerability and promoting the self-employment of Roma in Eastern Europe through financial inclusion. Retrieved from http://www-wds.worldbank.org/ external/default/WDSContentServer/WDSP/IB/2012/09/06/000333037_20120906002654/ Rendered/PDF/723310WP0P127200financial0inclusion.pdf

Thorbjørn, J. (2015). State of democracy, human rights and the rule of law in Europe. A shared responsibility for democratic security in Europe.

Treaty of Accession. (2005). Treaty concerning the accession of the Republic of Bulgaria and Romania to the European Union. Luxembourg.

Tremlett, A. (2009). Claims of "knowing" in ethnography: Realising anti-essentialism through a critical reflection on language acquisition in fieldwork. The Graduate Journal of Social Science (GJSS), Special Issue Lost (and found) in Translation, (December), 63-85.

Tremlett, A. (2014). Making a difference without creating a difference: Super-diversity as a new direction for research on Roma minorities. Ethnicities, 14(6), 830-848.

UNDP. (2003). Avoiding the dependency trap. United Nations Development Program. Bratislava. Retrieved from http://scholar.google.com/scholar?hl=en\&btnG=Search\&q=intitle:Avoiding+t he+Dependency+Trap\#1

van Baar, H. (2015). The perpetual mobile machine of forced mobility: Europe's Roma and the institutionalization of rootlessness. In Y. Jansen, J. de Bloois, \& R. Celikates (Eds.), The irregularization of migration in contemporary Europe: Deportation, detention, drowning (pp. 71-86). London/New York: Rowman \& Littlefield.

van Baar, H. (2017a). Contained mobility and the racialization of poverty in Europe: The Roma at the development - security nexus. Social Identities, $0(0), 1-17$.

van Baar, H. (2017b). Evictability and the biopolitical bordering of Europe. Antipode, 49(1), 212-230.

Van Baar, H., \& Ivasiuc, A. (2019). The securitization of the Roma in Europe (Vol. 49). New York: Palgrave Macmillan.

Vermeersch, P. (2012). Reframing the Roma: EU initiatives and the politics of reinterpretation. Journal of Ethnic and Migration Studies, 38(8), 1195-1212.

Vrăbiescu, I., \& Kalir, B. (2017). Care-full failure: How auxiliary assistance to poor Roma migrant women in Spain compounds marginalization. Social Identities, 4630, 520-532. (June).

Yildız, C., \& De Genova, N. (2017). Un/free mobility: Roma migrants in the European Union. Social Identities, 23(4), 1-17.

Open Access This chapter is licensed under the terms of the Creative Commons Attribution 4.0 International License (http://creativecommons.org/licenses/by/4.0/), which permits use, sharing, adaptation, distribution and reproduction in any medium or format, as long as you give appropriate credit to the original author(s) and the source, provide a link to the Creative Commons licence and indicate if changes were made.

The images or other third party material in this chapter are included in the chapter's Creative Commons licence, unless indicated otherwise in a credit line to the material. If material is not included in the chapter's Creative Commons licence and your intended use is not permitted by statutory regulation or exceeds the permitted use, you will need to obtain permission directly from the copyright holder.

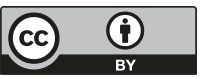

